Jurnal Kejuruteraan SI 1(3) 2018: 69-76

http://dx.doi.org/10.17576/jkukm-2018-si1(3)-10

\title{
Feasibility Study on Hybrid Solar Photovoltaic with Diesel Generator and Battery Storage Design and Sizing Using HOMER Pro ${ }^{\circledR}$
}

(Kajian Kebolehlaksanaan dalam Mereka Bentuk dan Pengsaizan ke atas Hibrid Solar Fotovoltan dengan Penjana Diesel dan Penyimpanan Bateri Menggunakan HOMER Pro ${ }^{\circledR}$ )

Amanda Halim ${ }^{\mathrm{a}, \mathrm{b}^{*}}$, Ahmad Fudholi ${ }^{\mathrm{a}}$, Kamaruzzaman Sopian ${ }^{\mathrm{a}}$, Mohd Hafidz Ruslan ${ }^{\mathrm{a}}$

${ }^{a}$ Solar Energy Research Institute, Universiti Kebangsaan Malaysia, Malaysia

Stephen J. Phillips ${ }^{\mathrm{b}}$

${ }^{b}$ Optimal Power Solutions (M) Sdn Bhd., Malaysia

ABSTRACT

World energy outlook in its latest 2017 edition by the International Energy Agency (IEA) reported that the global energy demand is rising slowly compared to the past, but still expected an expansion of 30\% in between today and 2040. Since energy demand and world population are exponentially growing, thus world cannot just depend on the exhaustible conventional sources to meet the demand. Renewable energy resources are the best alternative for conventional resources in meeting the world's increasing energy demand, mainly in electricity generation sector. Along with the expansion in the renewable energy technology, hybrid renewable energy system is configured in eliminating stand-alone drawbacks such as unpredictable power source, unreliable cost, and high initial and operational costs. This paper presents a study on a technique for hybrid renewable energy system design and sizing, and the feasibility of the system is determined using a hybrid optimisation of multiple energy resources pro (HOMER PrO ${ }^{\circledR}$ ) software. HOMER Pro ${ }^{\circledR}$ software has been widely used in configuring an optimised system, considering all the equipment modelled and sized in an efficient technique and the output from HOMER Pro ${ }^{\circledR}$ study is discussed.

Keywords: Hybrid renewable energy system; HOMER Pro ${ }^{\circledR}$; optimal design; optimal sizing

ABSTRAK

Tinjauan tenaga dunia dalam edisi terbaharu 2017 oleh Agensi Tenaga Antarabangsa (IEA) melaporkan bahawa permintaan tenaga global meningkat secara perlahan berbanding tahun sebelumnya, tetapi masih menjangka pengembangan sebanyak 30\% antara hari ini sehingga tahun 2040. Memandangkan permintaan tenaga dan penduduk dunia berkembang secara eksponen, dunia tidak boleh hanya bergantung pada sumber-sumber konvensional untuk memenuhi permintaan. Sumber tenaga boleh diperbaharui ialah alternatif terbaik kepada sumber konvensional dalam memenuhi permintaan tenaga dunia yang meningkat, terutamanya dalam sektor penjanaan elektrik. Seiring dengan pengembangan teknologi tenaga boleh diperbaharui, sistem tenaga boleh diperbaharui hibrid dikonfigurasikan dalam mengatasi kelemahan sistem tenaga tunggal seperti sumber kuasa yang tidak dapat diramalkan, kos yang tidak dapat dijangkakan, serta kos modal kos operasi yang tinggi. Kertas kajian ini membincangkan teknik mereka bentuk dan mengsaizkan sistem hibrid tenaga boleh diperbaharui dan kebolehlaksanaan sistem ditentukan menggunakan perisian pengoptimuman hibrid daripada sumber kepelbagaian tenaga sumber pro (HOMER Pro $\left.{ }^{\circledR}\right)$. Perisian HOMER Pro ${ }^{\circledR}$ telah digunakan secara meluas dalam mengkonfigurasi sistem yang optimum, dengan mempertimbangkan reka bentuk yang disaizkan mengikut teknik yang cekap dan hasil daripada simulasi HOMER Pro ${ }^{\circledR}$ dibincangkan.

Kata kunci: Sistem tenaga diperbaharui hibrid; HOMER Pro ${ }^{\circledR}$; reka bentuk optimum; pengsaizan optimum

\section{INTRODUCTION}

Natural gas, coal and unprocessed oil are currently the world's main sources of energy. Coal and natural gas were the most used energy fuels for generating electricity. However, population growth and technology development resulted in dependency on these exhaustible energies were perceived to be not relevant to meet the upcoming global's energy demand (Erdinc \& Uzunoglu 2012). The expansion is equivalent of adding another China and India into the current global energy demand. The projection was made based on the global economy growth which at the average of 3.4\% per year, the increase in world population from today's 7.4 billion to more than 9 billion in 2040 and also based on the study of urbanisation process that adds a city size of Shanghai to the world's urban population in every four months (IEA 2017). Whereas, in Malaysia, the load forecasting on energy demands has been projected to increase drastically since 2000 (Razak et al. 2009). Figure 1 shows that the main contribution to demand growth comes from India, while Southeast Asia 
comes in second with demand growing twice as pace of China. Overall, developing countries in Asia account for twothird of global energy growth, with the rest coming mainly from Middle East, Africa and Latin America.

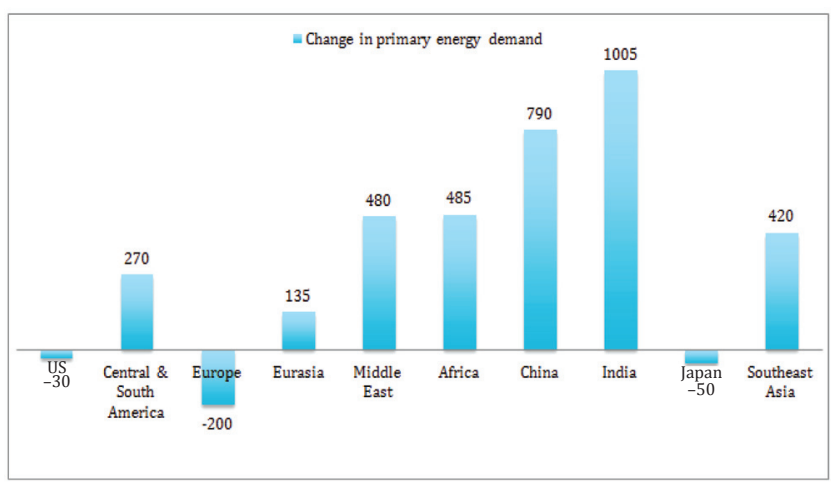

Sources: IEA 2017

FIGURE 1. Change in primary energy demand, 2016-40 (MToe)

The oil crisis of 1970's has brought solar energy applications to be noteworthy compared to other types of renewable energy (RE). This event resulted in disruptions of oil supply from the region, which created difficulties for those nations relying on energy exports.

As reported in IPCC four assessment report (IPCC 2017), since the last decade, the subject of RE received public attention as people are concerning the fact that the fossil fuels are becoming limited and their combustion produces, carbon dioxides $\left(\mathrm{CO}_{2}\right)$ which contributes to climate change (IPCC 2017). Renewable energy is appraised as the best alternative for fossil fuel in generating electricity. Solar photovoltaic (PV) energy technology is deemed the best solution in an effort to electrify off-grid rural areas. This is due to its ability to generate electricity; in fact, many implementations have been successfully done worldwide. Solar-PV technology produces no green house gas (GHG) emissions without any noise produced during the operations making it the most environmentally friendly technology (Joshi et al. 2009).

Nevertheless, when these resources are used as a single supply for a certain load, it has led to many shortcomings such as high in investment costs and the limitation in 24 hours supply due to the intermittent and uncertain nature of them. To overcome these problems, a concept, namely as hybrid renewable energy systems (HRES) has transpired. In a hybrid energy system various electrical energy generators and electrical energy storing device consolidated together to take care of the electrical power demand and country zone, or even entire group (Khare et al. 2013). HRES, as known by the name is a combination of two or more energy sources. Normally, combination of RE such as solar energy, wind energy, and geothermal with the common conventional sources such as fuels (diesel generator) with support from the battery storage are used for power generation to electrify the load locally in stand-alone mode, and as well be operated in parallel with grid power system whenever applicable (Mundada et al. 2016) (Ekren \& Ekren 2009). Due to its complexity in configuration, hybrid solar system composed by two or more energy sources has to be designed and sized to reduce the risk of failure in its operation. Several studies have been conducted on a wide variety of methods and software used in designing, sizing, optimising, and operation controlling the hybrid energy system (Luna-Rubio et al. 2012; Yilanci et al. 2009).

This paper's objective is to explain by means of using the approach in designing and sizing a typical hybrid solar-PV diesel with battery storage system and the feasibility of the system is determined by using HOMER Pro ${ }^{\circledR}$.

\section{HOMER PRO ${ }^{\circledR}$ SOFTWARE}

HOMER software is a computer model developed by the U.S. National Renewable Energy Laboratory (NREL). It is a tool that has been used in microgrid design optimisation. HOMER helps in planning, designing and navigating the complexities of building cost effective and reliable microgrid composed by the conventional and renewable power, storage and load management. HOMER simulates the feasibility of the modelled system, giving the levelized cost of energy (LCOE) and net present cost (NPC) as the measurement parameters. HOMER is being developed from time to time by NREL in fixing the bugs as well as upgrading the old version to a better newer version. Table 1 shows the brief information on the HOMER software major development.

TABLE 1. HOMER major development in version history

\begin{tabular}{ll}
\hline \multicolumn{1}{c}{ Version } & \multicolumn{1}{c}{ Year } \\
\hline HOMER Original Version 1.0 & February, 2000 \\
HOMER Legacy Version 2.0 & July, 2003 \\
HOMER 2 & June, 2010 \\
HOMER Pro & October, 2014 \\
HOMER Pro $^{\circledR} 3.11 .4$ & March, 2018 \\
\hline
\end{tabular}

In this study, latest HOMER Pro ${ }^{\circledR}$ has been extensively used for the system feasibility study. Figure 2 shows the homepage of the HOMER Pro ${ }^{\circledR}$ summarising the information on system/model, system architecture, description, economic and location.

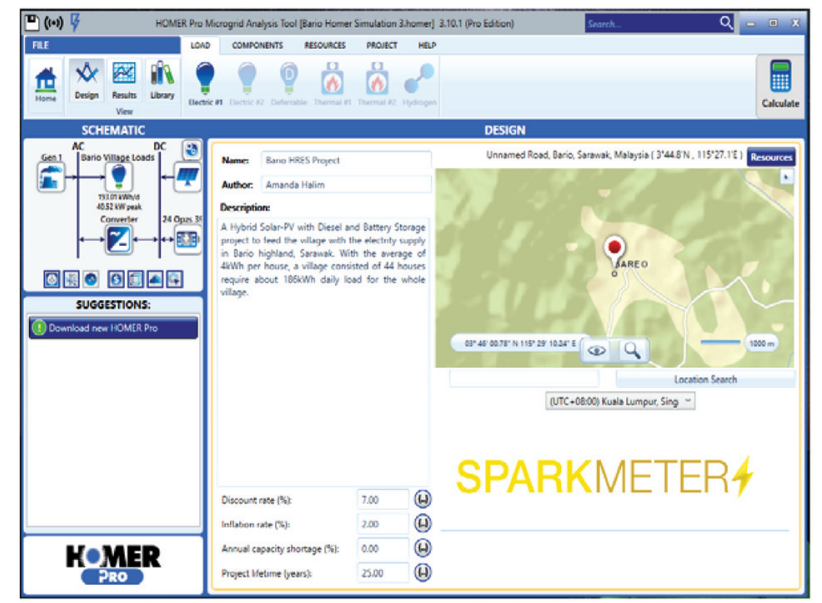

FIGURE 2. The schematic diagram of a modelled system as well as the main page in HOMER Pro ${ }^{\circledR}$ 
HOMER Pro ${ }^{\circledR}$ requires several inputs in simulating the modelled system. Those include the items listed in Table
2. In general, HOMER Pro ${ }^{\circledR}$ performs three principal tasks simulation, optimisation, and sensitivity analysis.

TABLE 2. General input required by HOMER Pro ${ }^{\circledR}$ for system simulation

\begin{tabular}{|c|c|}
\hline Input & Condition \\
\hline Meteorological Data & Nature resources i.e. solar radiation, wind speed, temperature. \\
\hline Load Profile & $\begin{array}{l}\text { Demand for electric that the power system must meet at specific time. i.e. village loads, hospital loads, } \\
\text { school loads. }\end{array}$ \\
\hline Component Characteristics & $\begin{array}{l}\text { Any part of the system that generates, delivers, converts or stores the energy. i.e. PV modules, inverter, } \\
\text { diesel generator, battery storage. }\end{array}$ \\
\hline Economic Data & $\begin{array}{l}\text { Specific costs on each equipment such as capital, replacements, maintenance and the general cost for } \\
\text { the whole project such as system fixed capital cost, maintenance, and penalty cost on the emissions are } \\
\text { considered in simulation and optimisation stages. Based on these cost, the NPC of each configuration } \\
\text { is calculated. }\end{array}$ \\
\hline Search Space & Variety in sizing each component for the optimisation. \\
\hline Controller & Technical data including dispatch strategy and operating reserve. \\
\hline
\end{tabular}

\section{HOMER PRO ${ }^{\circledast}$ INPUT DATA}

In this section, an installed hybrid solar-PV with diesel generator and energy storage at $\mathrm{Kg}$. Bario, Sarawak was used as a case study/reference. Located close to the SarawakKalimantan border, $178 \mathrm{~km}$ to the east of Miri, Bario highland holds a community of 13 to 16 villages. The following data was gathered during a comprehensive site survey conducted by the engineers from Optimal Power Solutions Sdn. Bhd. Table 3 shows the details of the power ( $\mathrm{kWh}$ ) consumption for each house at the village. The most common load types were listed and each of them consume the power at their watt rating, and then the load was recorded by estimating the hourly usage of those in one day. The total daily load for each house was recorded at $4.17 \mathrm{kWh}$ and the pattern of consumption was assumed to be similar for the rest of the houses in the village. The total daily load for the whole village was at $183.64 \mathrm{kWh}$. Figure 3 shows that the load profile contains two bumps caused by the electricity demand at two particular times; 1) at 8 a.m. when the villagers get ready for work and school, and 2) at 8 p.m. when everybody was home for dinner and night activities.

TABLE 3. Village load data taken from the site survey

\begin{tabular}{|c|c|c|c|c|c|c|}
\hline Room Type & Load Type & $\begin{array}{l}\text { No of Load } \\
\text { (nos) }\end{array}$ & $\begin{array}{l}\text { Load Watt } \\
\text { (W) }\end{array}$ & $\begin{array}{l}\text { Total Load } \\
\text { (W) }\end{array}$ & $\begin{array}{l}\text { Daily Usage } \\
\text { (hr) }\end{array}$ & $\begin{array}{l}\text { Daily Usage } \\
(\mathrm{kWh})\end{array}$ \\
\hline \multirow[t]{12}{*}{ House } & Fridge & 1 & 150 & 150 & 5.7 & 0.86 \\
\hline & Freezer Box & 0 & 250 & 0 & 5.7 & 0 \\
\hline & Lamps & 6 & 36 & 216 & 2.67 & 0.58 \\
\hline & Washing Machine & 1 & 300 & 300 & 1 & 0.3 \\
\hline & TV & 1 & 150 & 150 & 5 & 0.75 \\
\hline & Iron & 1 & 300 & 300 & 1 & 0.3 \\
\hline & Radio & 1 & 30 & 30 & 5 & 0.15 \\
\hline & Fans & 2 & 65 & 130 & 4.82 & 0.63 \\
\hline & Power Points & 2 & 100 & 200 & 3.1 & 0.62 \\
\hline & & & & \multicolumn{2}{|c|}{ Total Daily Load/house (kWh) } & 4.17 \\
\hline & & & & \multicolumn{2}{|c|}{ Number of houses } & 44 \\
\hline & & & & \multicolumn{2}{|c|}{ Total Daily village load (kWh) } & 183.64 \\
\hline
\end{tabular}

The load profile pattern in HOMER was set to be the same throughout the whole year as shown in Figure 4. This is due to the pattern of climate in Malaysia, which is averagely the same throughout the year. In HOMER Pro ${ }^{\circledR}$, the meteorological data such as solar radiation, wind speed and temperature are obtained from the National Aeronautics and Space Administration (NASA) database. The data were fed into the software in the form of monthly averages or time data series (Bahramara et al. 2016). Characteristics and potential of solar energy at selected location are analysed based on mean monthly global solar radiation as well as the monthly clearness index (Olatomiwa et al. 2016). For this simulation, the solar radiation and temperature data for this specific location in Bario, Sarawak coordinated at $03^{\circ} 44^{\prime} 13^{\prime \prime} \mathrm{N}$ $115^{\circ} 28^{\prime} 10^{\prime \prime} \mathrm{E}$ were obtained. The average solar radiation was at $5.11 \mathrm{kWh} / \mathrm{m}^{2} /$ day, while the average temperature was at $24.1^{\circ} \mathrm{C}$ 


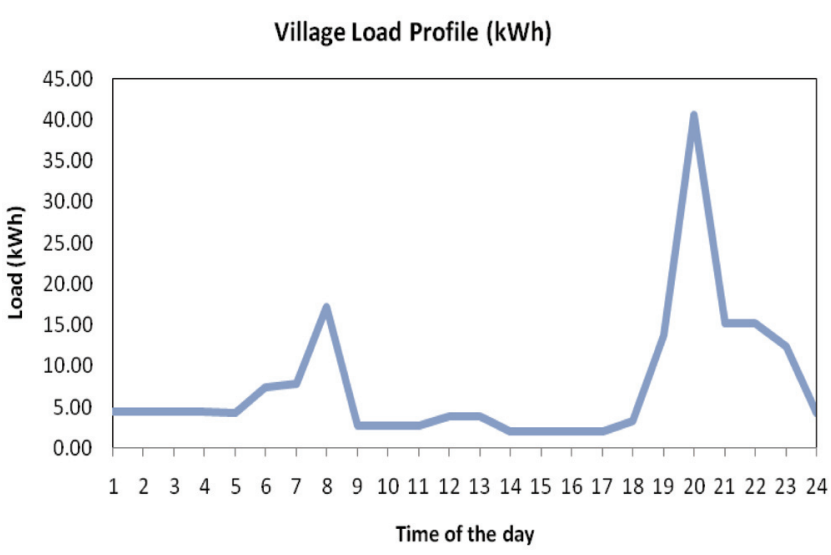

FIGURE 3. Daily village hourly load (kWh)

Global horizontal radiation and air temperature monthly averaged values over 22-year period (July 1983 - June 2005). The monthly solar radiation and temperature can be referred in Figure 4 and Figure 5. The isolation reaching the earth's surface hinge on the cloudiness or clearness of the sky, which in turn depends on the season of the year (Shukla et al. 2015).

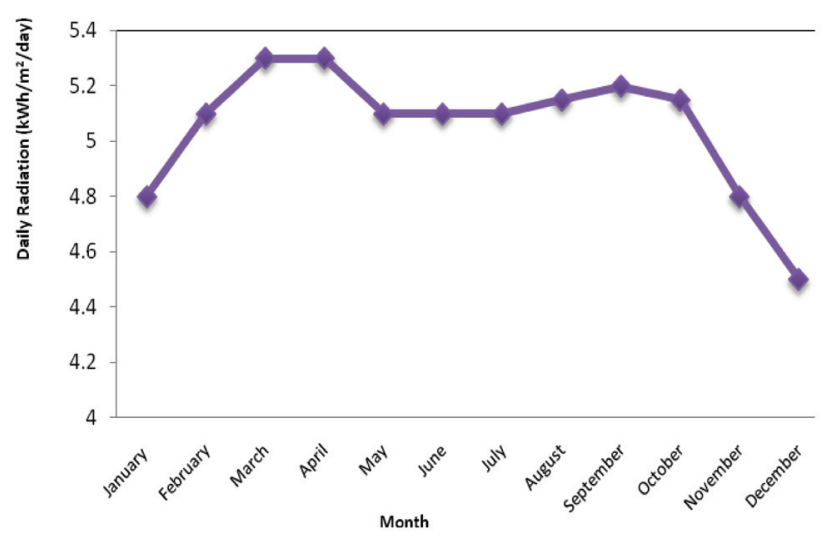

FIGURE 4. Plotted solar radiation in $\mathrm{kWh} / \mathrm{m}^{2} /$ day at Bario, Sarawak by NASA database. Data downloaded on 13-Mar-18 at 11:07:04 PM from NASA surface meteorology and solar database

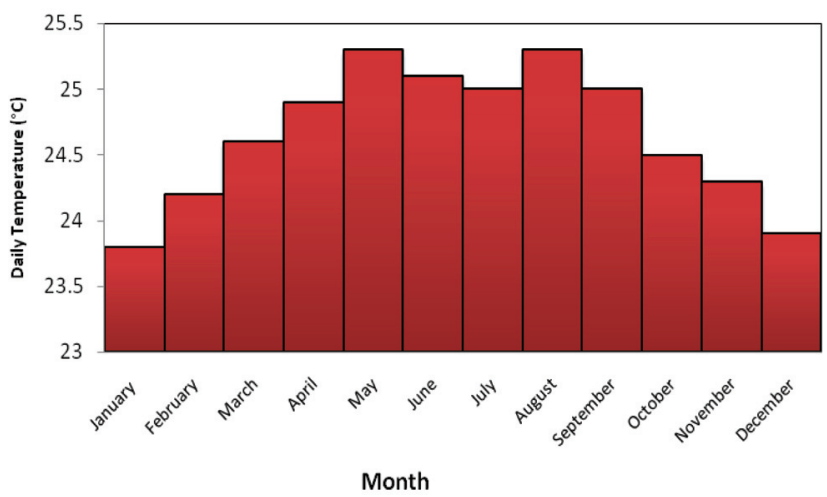

FIGURE 5. The plotted temperature in Bario, Sarawak by NASA database. Data downloaded on 13-Mar-18 at 11:07:09 PM from NASA surface meteorology and solar database.
EQUIPMENT SIZING AND DESIGN

In this system modelling, 220 pieces of $255 \mathrm{~W}$ of CNPV panels were installed resulted in $56.1 \mathrm{~kW}$ of power contribution coming from the PV. The sub arrays of the PV panel were designed as to meet the requirement of the maximum power point tracker (MPPT) solar charger input such as the maximum DC input. Table 4 shows the input from the system as well as PV panels considered in the sub array design. The information on how the configuration of the whole PV modules was installed is as per details in Table 5 .

In HOMER Pro ${ }^{\circledR}$, the cost of the PV was determined in a $\mathrm{kW}$ basis. To get the direct analysis from HOMER, the search space for PV was directly based on the total of $56.1 \mathrm{~kW}$ installed. In hybrid energy system, the principle segments are power inverter as a conversation medium in feeding up the village AC loads (Eroglu et al. 2011). The inverter is an electronic device to convert the DC power into AC power.

TABLE 4. PV Panel details and system input for sub array design

\begin{tabular}{|c|c|c|c|}
\hline \multicolumn{3}{|c|}{ System Input } & \\
\hline 1 & \multicolumn{2}{|c|}{ Required $\mathrm{kWp}$ of Solar $(\mathrm{kW})$} & 56.1 \\
\hline 2 & \multicolumn{2}{|c|}{ Maximum Inverter DC Input (V) } & 160 \\
\hline 3 & \multicolumn{2}{|c|}{ Maximum Panel Working Temp (Celsius) } & 60 \\
\hline 4 & \multicolumn{2}{|c|}{ Minimum Panel Working Temp (Celsius) } & 25 \\
\hline \multirow[t]{7}{*}{ PANEL DATA } & \multicolumn{2}{|c|}{ Panel Type to be used } & CNPV $255 \mathrm{M}$ \\
\hline & \multicolumn{2}{|c|}{ Watt per module [W] } & 255 \\
\hline & \multicolumn{2}{|c|}{$V_{0}$} & 37.9 \\
\hline & \multicolumn{2}{|l|}{$V_{m p}^{o c}$} & 31.3 \\
\hline & & 8.15 \\
\hline & \multicolumn{2}{|c|}{ Max System Voltage $(V)$} & 1000 \\
\hline & \multicolumn{2}{|c|}{ Short-circuit current $\left(I_{\mathrm{sc}}\right)$} & 8.7 \\
\hline \multicolumn{4}{|c|}{ TABLE 5 . PV array configuration } \\
\hline \multicolumn{2}{|c|}{ PV Array Element } & Capacity & Unit \\
\hline \multicolumn{2}{|l|}{ PV Module } & 255 & Watt \\
\hline \multicolumn{2}{|c|}{ String } & 5 & Nos. \\
\hline \multicolumn{2}{|c|}{ PV Module/String } & 4 & Nos. \\
\hline \multicolumn{2}{|c|}{ Sub Array } & 5.1 & $\mathrm{~kW}$ \\
\hline \multicolumn{2}{|c|}{ Total Sub Array } & 11 & Nos. \\
\hline \multicolumn{2}{|c|}{ Total Installed PV } & 56.1 & $\mathrm{~kW}$ \\
\hline
\end{tabular}

The configuration of two units of $17 \mathrm{~kW}$ inverters operating in parallel is perceived as an advantage as the system can be operated by a single inverter whenever load demand is low and the second inverter will be operated when the load is high. Both inverters operate in parallel with the maximum power at $34 \mathrm{~kW}$. These inverters operate on a $48 \mathrm{~V}$ DC bus bar. Diesel generator is commonly known as a backup power sources for a typical HRES. For this case, the system was designed with the requirement that $30 \%$ of the energy contribution must come from the diesel generator, while the other $70 \%$ came from the RE source with battery. The system could also be configured using the diesel generator charging the battery storage whenever it is required. This system was 
designed with a $30 \mathrm{~kW}$ of Cummins diesel generator. Battery storage is one of the important equipment in a hybrid system. As energy storage, battery functions to store the excess energy produced by solar and will discharge the stored energy whenever other main sources are not available. A battery bank is utilised as a reinforcement system and it likewise keeps up consistent voltage over the electrical load. It is a conventional way to deal with store electrical power with high effectiveness (Malheiro et al. 2015). Several aspects need to be considered in designing the battery system to run the parallel operation. This includes the system voltage. In this case, the system was configured to run on a $48 \mathrm{~V}$ DC bus bar. The A600 solar dry cells from Sonnenschein were used. The particulars of the cell are tabulated in Table 6 .

TABLE 6. Cell specifications from Sonnenschein A600 solar dry cell

\begin{tabular}{lc}
\hline Brand & Sonnenschein (Germany) \\
\hline Type & Dry Cell (Gel) \\
Model & 24 OPsZ 3920 Ah \\
Voltage per Cell (VPC) & $2 \mathrm{~V}$ \\
Cell Ampere hour (Ah) & $3920 \mathrm{Ah}$ \\
Operating Voltage & $1.8 \mathrm{~V} /$ cell at $20^{\circ} \mathrm{C}$ \\
\hline
\end{tabular}

The string design of the whole battery system is as in the schematic diagram in Figure 6 . The battery storage system consisted of 72 units of cell. 24 cells were connected in three series to form $48 \mathrm{~V}$ line, and three battery strings were connected in parallel resulted in total installed battery storage of $564.48 \mathrm{kWh}$. The commercial input for the equipment in HOMER Pro ${ }^{\circledR}$ simulation can be found in Table 7. The costs shown were at $\mathrm{kW}$ basis.

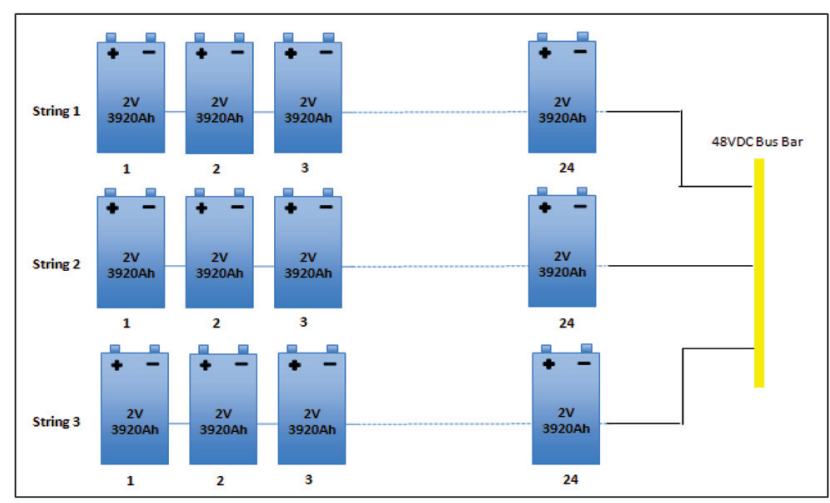

FIGURE 6. Arrangement of the cells in parallel and series forming a battery storage system for a $48 \mathrm{~V}$ DC bus bar at $564.48 \mathrm{kWh}$

TABLE 7. Base cost and installed capacity for each equipment

\begin{tabular}{lccccc}
\hline Equipment & Capacity & Capital (RM) & Replacement (RM) & Operation \& Maintenance (RM) & Installed Capacity \\
\hline Solar PV & $1 \mathrm{~kW}$ & $2,000.00$ & $2,000.00$ & $10 /$ year & $56.1 \mathrm{~kW}$ \\
Inverter & $1 \mathrm{~kW}$ & $2,000.00$ & $1,500.00$ & $150 /$ year & $34 \mathrm{~kW}$ \\
Diesel Generator & $1 \mathrm{~kW}$ & 830.00 & 500.00 & $0.350 /$ hour & $30 \mathrm{~kW}$ \\
Battery & $1 \mathrm{unit}$ & $1,500.00$ & $1,000.00$ & $10 /$ year & $564.5 \mathrm{kWh}$ \\
\hline
\end{tabular}

Other than the cost for equipment, HOMER Pro ${ }^{\circledR}$ also requires the user to consider the economics sensitivity variables such as listed in Table 8. System fixed capital cost is the capital cost that occurs at the start of the project regardless of the size or architecture of the power system. It can be referred as the structure supporting the system such as power house, civil work at site, lands and fencing. While the system fixed operation and maintenance (O\&M) costs are the annually recurring costs regardless of the size or architecture of the power system. Homer will simulate the designed system based on the estimation of installing cost, replacement cost, O\&M cost, fuel and interest rate (Rodrigues et al. 2011).

TABLE 8. Economic input for HOMER Pro $^{\circledR}$ simulation

\begin{tabular}{ll}
\hline \multicolumn{1}{c}{ Economic Input } & \multicolumn{1}{c}{ Value } \\
\hline Nominal Discount Rate & $7 \%$ \\
Expected inflation rate & $2 \%$ \\
Project lifetime & 25 years \\
System fixed capital cost & RM25,000 \\
System fixed O\&M cost & RM5,000 \\
\hline
\end{tabular}

Therefore, both costs have no effect on the system size but will eventually affect the NPC. As per the abovegiven input parameters and constraints, simulation has been carried out using HOMER Pro ${ }^{\circledR}$ software (Kazem et al. 2013). However, this paper only focused on the technical side of the feasibility, therefore the commercial and economic details for the equipment as well as the whole project is estimated current market reference.

\section{DISCUSSION ON HOMER RESULT AND OUTPUT}

Overall, the system architecture modelled was feasible with the equipment installed as per Figure 7. The control system embedded in the PIM $17 \mathrm{~K}$ acted as a controller to manage the $\mathrm{kW}$ movement in the system. In this case, OPS PV Net was used. While monitoring the demand from the AC load, the controller measured all the available sources and calculated the figures based on the sources priority to ensure that the load was constantly supplied. 


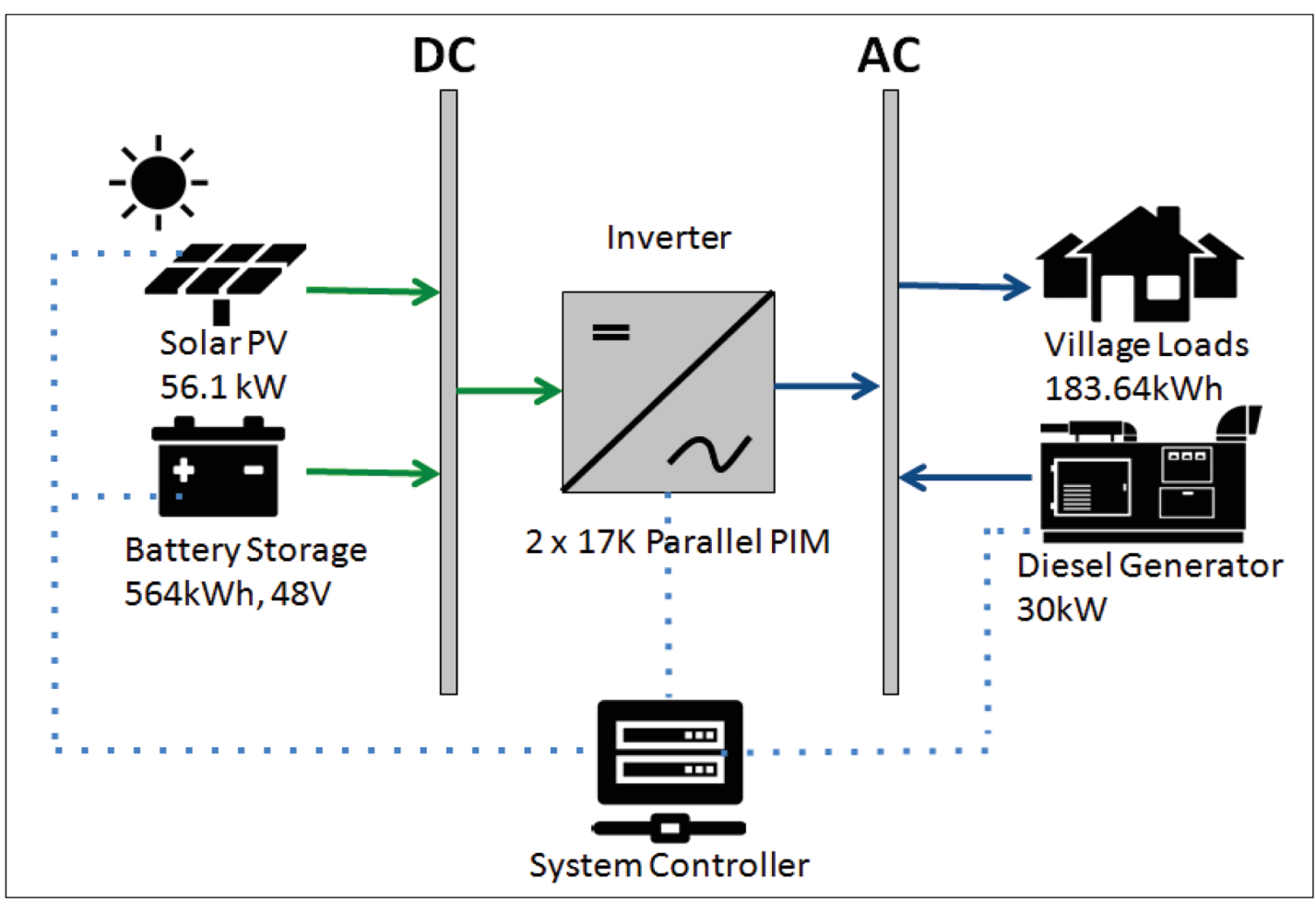

FIGURE 7. Schematic diagram of the system architecture modelled in HOMER Pro ${ }^{\circledR}$

HOMER Pro ${ }^{\circledR}$ provided the system production summary as in Figure 8 . The load was being powered mostly by the renewable sources, where the contribution from solar was $67.6 \%$, while the diesel engine contributed $32.4 \%$ of the total production.

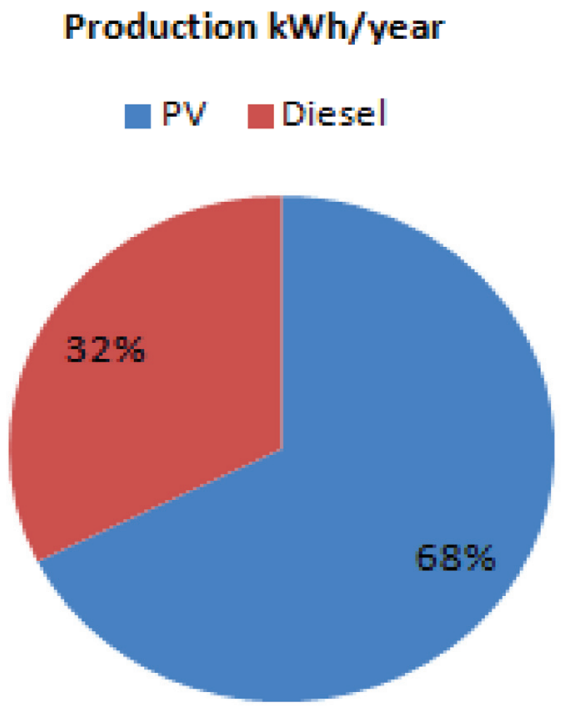

FIGURE 8. Energy production from PV and Diesel calculated by HOMER Pro ${ }^{\circledR}$ in a year
The result captured from HOMER Pro ${ }^{\circledR}$ in Figure 9 explained that the modelled system is feasible to run an average of $186 \mathrm{kWh}$ of village daily loads. Figure 9 shows that the day started (8 A.M.) with the loads were being powered up by the engine and solar power combined. Moving towards noon, solar radiation escalated, the controller calculated the sources availability and priority, decided to call off the engine, and the system run solely on the generated solar power. At the same time, the excess power generated from the solar PV was also being consumed by the battery for charging process. The battery stored the energy to be used during night time when the solar PV is unavailable. Starting from 7 p.m., the solar PV stops producing, and the battery will kick in to feed the demand. At night time, whenever the demand is high, and the battery could not cope with the demand, the controller called the engine back on line to support the power feeding to the village. The battery normally will power the small demand up for the rest of the night until the next morning. The controller manages the energy to make sure that the energy movement is smooth and the power supply to the village is uninterrupted. In terms of economic, HOMER Pro ${ }^{\circledR}$ analysed the NPC at RM644,707.80 and LCOE at RM0.643/kWh for the system to run in 25 years' time. The LCOE was calculated based on the economic input considering all the aspects such as the diesel price using the Malaysian currency (RM). 


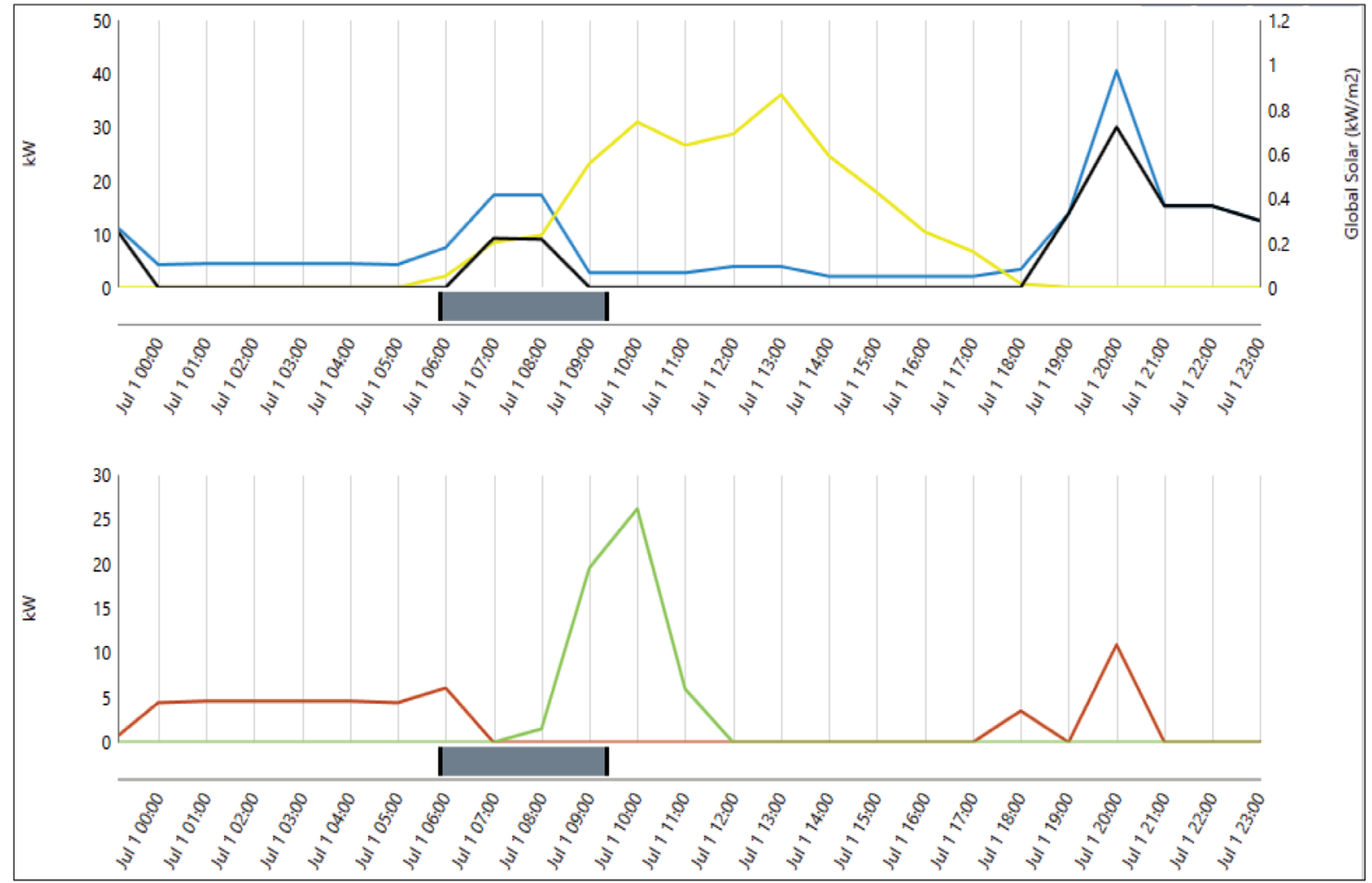

\begin{tabular}{|l|l|l|l|l|l|l|}
\hline Solar kW & $\begin{array}{l}\text { Ac Primary } \\
\text { Load }\end{array}$ & $\begin{array}{l}\text { Engine } \\
\text { Output }\end{array}$ & $\begin{array}{l}\text { Battery } \\
\text { Charging }\end{array}$ & $\begin{array}{l}\text { Battery } \\
\text { Discharging }\end{array}$ \\
\hline
\end{tabular}

FIGURE 9. System running in a day operation. The analysis was obtained from HOMER Pro ${ }^{\circledR}$ simulation

CONCLUSION

The use of HOMER Pro ${ }^{\circledR}$ in determining the feasibility of a system especially in a technical aspect is very useful. It helps a lot of system designers to come up with and finalise the design system, especially when it comes to dealing with projects of many requirements. In fact, HOMER Pro ${ }^{\circledR}$ could give the estimation on how the system would operate throughout the day. HOMER Pro ${ }^{\circledR}$ also helps in preparing a full report of a modelled system and can be used as a material to support the designed model. However, a basic knowledge of sizing the system must be improved as the simulation will become easier if the complete set of configurations was prepared before running the software. A system with the lowest LCOE and NPC is preferred, but the best configuration may be selected based on other criteria, considering the perspective of the stakeholders.

\section{ACKNOWLEDGEMENT}

Thank you to the Malaysia Higher Education Ministry (KPT) for the DLP/1/2015/ST02/UKM/03/1 and Universiti Kebangsaan Malaysia (UKM) for the (GGPM-2014-029). Thank you to Solar Energy Research Institute (SERI) for all the facilities and technical assistance provided.
REFERENCES

Bahramara, S., Parsa Moghaddam, M. \& Haghifam, M.R 2016. Optimal panning of hybrid renewable energy systems using HOMER: A review. Renewable and Sustainable Energy Reviews 62: 609-620.

Eroglu, M., Dursun, E., Sevencan, S., Song, J., Yazici \& O. Killic., 2011 A mobile renewable house using PV/wind/ fuel cell hybrid power system. International Journal of Hydrogen Energy 36: 7985-7992

Ekren, B. Y. \& Ekren, O. 2009. Simulation based size optimization of a PV/wind hybrid energy conversion system with battery storage under various load and auxiliary energy conditions. Applied Energy 86(9): 1387-1394.

Erdinc, O. \& Uzunoglu, M. 2012. Optimal design of hybrid renewable energy systems: Overview of different approaches. Renewable \& Sustainable Energy Reviews 16(3): 1412-1425.

International Energy Agency (IEA). 2017. World Energy Outlook 2017 - Executive Summary-English version. International Energy Agency. www.iea.org

Intergovernmental Panel on Climate Change. (IPCC). 2017. Fourth Assessment Report, Climate Change 2017, Cambridge University Press. 
Joshi, A., Dincer, I. \& Reddy, B.V. 2009. Performance analysis of photovoltaic system; A review. Renewable and Sustainable Energy Reviews 13(8): 1884-1897.

Kazem, H.A, Ali, S.Q., Alwaeli, A.H.A. \& Mani, K. 2013. Life-cycle cost analysis and optimization of health clinic PV system for a rural area in Oman. Proceedings of the World Congress on Engineering 2: 3-5.

Khare, V., Nema, S. \& Baredar, P. 2013. Status of solar wind renewable energy in India. Renewable and Sustainable Energy Reviews 27: 1-10

Mundada, A.S. Shah, K.K. \& Pearce, J.M. 2016. Levelized cost of electricity for solar photovoltaic, battery and cogen hybrid systems. Renewable and Sustainable Energy Reviews 57: 692-703.

Luna-Rubio R., Trejo-Perea, M., Vargas-V- Vazquez, D. \& Rios-Moreno, G.J. 2012. Optimal sizing of renewable hybrids energy systems: A review of methodologies. Solar Energy 86(4): 1077-1088.

Malheiro. A, Castro, P.M., Lima, R.M. \& Estanqueiro, A. 2015. Integrated Sizing and Scheduling of wind/PV/ diesel/battery isolated systems Renewable Energy 83: 646-657

Olatomiwa, L., Mekhilef, S. \& Ohunakin, O.S. 2016. Hybrid renewable power supply for rural health clinic (RHC) in six geo-political zones of Nigeria. Sustainable Energy Technologies and Assessments 13: 1-12

Razak, F.A., Shitan, M., Hashim, A.H. \& Zabidin, I.Z. 2009. Load forecasting using time series models. Jurnal Kejuruteraan 21: 53-62.

Rodrigues, A., Dentinho, T., Silva, C. \& Azevedo, E. 2011. Cost benefit analysis to select clean energy solutions in dairy farm milk collection posts in Azores. Journal of Energy and Power Engineering 5(4): 308-316.
Shukla, K., Rangnekar, S. \& Sudhakar, K. 2015. Comparative study of isotropic and anistropic sky models to estimate solar radiation incident on titled surface: A case study for Bhopal, India. Energy Reports 1: 96-103.

Yilanci, A., Dincer, I. \& Ozturk, H.K. 2009. A review on solarhydrogen/fuel cell hybrid energy systems for stationary applications. Progress in Energy and Combustion 35(3): 231-244.

*Amanda Halim, Ahmad Fudholi, Kamaruzzaman Sopian, Mohd Hafidz Ruslan

Solar Energy Research Institute,

Universiti Kebangsaan Malaysia,

43600 Bangi, Selangor, Malaysia

Stephen J. Phillips

Optimal Power Solutions (M) Sdn Bhd,

118, Block A3, Leisure Commerce Square,

Jln PJS 8/9, Pjs 8, 46150 Petaling Jaya, Malaysia

*Corresponding author email:

sitiamandaabhalim@gmail.com

Received date: $7^{\text {th }}$ May 2018

Accepted date: $14^{\text {th }}$ August 2018

Online first date: $1^{\text {st }}$ October 2018

Published date: $30^{\text {th }}$ November 2018 